\title{
Economic Activities of German Local Authorities - Critical Notes from a Public Finance Perspective
}

UDK: 338:336.1(430)(045)

\author{
Thomas Döring \\ Darmstadt University of Applied Sciences \\ thomas.doering@h-da.de \\ Birgit Aigner-Walder \\ Carinthia Institute for Advanced Studies \\ aigner-walder@carinthia.ihs.ac.at
}

\begin{abstract}
Within the last two decades, local authorities throughout Germany have increased their revenue by stepping up their economic activities. Municipal business ventures range from energy supply to catering services and even food retail, and are almost all justified by some public purpose or other. In 2010, local authorities in western Germany earned 5.3 pc of total revenue from their economic activities, compared to 4.7 pc in 1992. The share in eastern Germany was rising over the same period from 4.3 pc to 5.1 pc. In fact in 2010 a total of $€ 9.3$ billion was earned by local authorities this way (compared to $€ 6.0$ billion in 1992). The aim of the paper is to examine this trend from the perspective of public finance by drawing on the theory of public goods, the theory of fiscal federalism and some aspects of new political economy. Although the results vary somewhat depending on the angle taken, on balance the new economic activities by local government in Germany must be assessed negatively.
\end{abstract}

Key words: local public finance, publicly provided goods, local public enterprises, fiscal federalism, new political economy

JEL: H42, H71, L32

\section{Introduction}

Hardship breeds creativity: In times of budget deficits - as most of the local authorities in Germany have experienced during the last 20 years municipalities increasingly come up with new commercial ideas in an attempt to generate more revenue. Councils no longer stop at supplying electricity, gas and water or collecting garbage all of which are traditional local public economic activities. They have also begun to offer various other goods 
and services through publicly owned businesses. These economic activities include transport, IT and telecom services. Some local authorities own gravel pits, quarries and vineyards. Others run catering services, flowers shops, restaurants and hotels, travel agencies, energy consultancies, fingernail studios or even car washes. Still other councils take on the repair of private vehicles at their local transport services centers (Meyer \& Scholl 1999; Fuest et al., 2002; Döring 2003a; Bardt \& Fuest 2007).

The aforementioned examples of new economic activities of German local authorities in order to conquer existing budget deficits are by no means exceptions; in fact within the last two decades local authorities throughout Germany have increased their entrepreneurial activities more than ever before. In 20105.3 pc of local authorities' revenue in western Germany came from their own business activities, up from 4.7 pc in 1992; in eastern Germany in the same period the share rose from 4.3 pc to 5.1 pc. The business income reported here comprises the sale of electricity, gas, water, and agricultural and forestry products, renting and leasing, and profits from economic enterprises and company shareholding, as well as license taxes and concession levies. In all, in 2010 commercial earnings contributed almost $€ 9.3$ billion to local government budget, which represents an increase of more than 50 pc compared to $€ 6.0$ billion in 1992 (Statistisches Bundesamt 2011). Considering the last decade (1999-2010), Table 1 shows from a regional perspective the development of local public revenues deriving from economic activities.

Table 1: Local public revenues from economic activities on a regional level (in million Euro - change in percentage points)

\begin{tabular}{|l|r|r|r|}
\hline German Federal States & 1999 & 2010 & $\Delta 1999-2010$ \\
\hline Baden-Württemberg & 1,520 & 1,496 & -1.57 \\
\hline Bavaria & 1,323 & 1,844 & +39.38 \\
\hline Brandenburg & 216 & 242 & +12.04 \\
\hline Hesse & 650 & 674 & +3.69 \\
\hline Lower Saxony & 633 & 791 & +24.96 \\
\hline Mecklenburg-Western Pomerania & 196 & 210 & +7.14 \\
\hline North Rhine-Westphalia & 1,847 & 2,129 & +13.24 \\
\hline Rhineland-Palatinate & 382 & 511 & +33.77 \\
\hline Saarland & 76 & 73 & -3.94 \\
\hline Saxony & 392 & 450 & +14.79 \\
\hline Saxony-Anhalt & 211 & 330 & +56.39 \\
\hline Schleswig Holstein & 240 & 277 & +15.41 \\
\hline Thuringia & 213 & 243 & +14.08 \\
\hline West Germany & 6,671 & 7,799 & +16.91 \\
\hline East Germany & 1,228 & 1,477 & +20.27 \\
\hline Total & 7,899 & 9,276 & +17.43 \\
\hline
\end{tabular}

Source: Statistisches Bundesamt (2011); own calculations 
As can be seen from Table 1, the quantity of economic activities of local authorities - indicated by revenues stemming from these activities - did increase from 1999 up to 2010 by a two-digit growth rate: In Germany on the whole, local economic activities did expand about 17.43 pc. Only the local authorities in Baden-Württemberg ( -1.57 pc) as well as Saarland (-3.94 pc) had to face decreasing revenues concerning their economic activities within the time period under consideration. The most extensive growth of business activities of local authorities took place in Saxony-Anhalt; the related revenues increase by 56.39 pc, followed up by the cities and municipalities in Bavaria $(+39.38 \mathrm{pc})$ and the Rhineland-Palatinate $(+33.77 \mathrm{pc})$. Altogether, from 1999 up to 2010 the biggest extension of local public economic activities is reported for eastern Germany (20.27 pc), whereas the revenues of local authorities in western Germany stemming from business activities did only increase by 16.91 pc within the same time period. In both cases, cities and municipalities did expand their commercial activities in account of the private economic sector.

There are many reasons for this commercial expansion, one being the altered economic environment. For instance, in European Union the competition policy of the last two decades has resulted in the effect that traditional (usually monopolized) areas of business of municipal companies in Germany are coming under growing pressure from private competition (European Commission, 1996 and 2000; Hrbek \& Nettesheim, 2002). Therefore, with revenues in these areas falling, tackling new fields of business is now regarded by local government as a way of compensating for the loss of income. In general it is seen as a way of earning additional revenue for local public budgets and hence indirectly helping local councils meet their responsibilities. Ultimately, expanding commercial activity is also envisaged as a way of safeguarding public jobs under threat as the turnover of existing municipal companies shrinks.

Yet this expansion strategy has encountered sharp criticism, and its economic impact has become the subject of lively debate in Germany (Otting, 1997a; Fuest et al., 2002; Döring, 2003a; Bardt \& Fuest 2007; Scherf, 2010; focusing local public banks Döring, 2003b). Economic activities by local government are mainly censured by private companies and business associations, who are critical of the unequal conditions for the competition between private and local public enterprise claiming that commercial activities by local authorities should be restricted. Against this background, the paper examines the problem from various perspectives. In the first step, attention is focused below on the existing legal limitations currently imposed on local public economic activities in Germany (chapter 2). Furthermore, the described trend is analyzed from a public finance perspective by drawing on the theory of public goods (chapter 3 ), the theory of fiscal federalism (chapter 4) and some aspects of new political economy (chapter 5). 


\section{Legal restrictions on local public economic activities}

The present legal framework places restrictions on the economic activities of local authorities in Germany. The German Constitution does not disallow the broadening of local public economic activities in principal, but regional laws (passed by the German federal states) regulate the legality of these activities in the charters which govern the local institutional setup (so called municipal ordinances). Although these vary somewhat between the German states, in the majority of them economic activities by local authorities are permitted if (Kuntze, 2002):

- The activity is justified by a public purpose.

- The type and extend of the activity correspond with the financial capacity of the local authority and the prospective need for the public service.

- The purpose cannot be fulfilled more or even equally effectively by the private sector (the so called subsidiary clause).

- In addition, Art. 28 Sect. 2 of the German constitution rules that a local authority may only undertake economic activities locally.

With respect to the aforementioned legal requirements, the »public purpose» item is the crucial limiting criterion regarding the commercial behavior of local government. Following a ruling by the Federal Constitutional Court, however, it is up to local political representatives to decide independently whether a public purpose exists. Consequently, the legal restrictions placed on local public economic activities are in reality rather weak. General consensus is limited to the view that a public purpose does not exist if the public enterprise solely serves fiscal objectives. The »financial capacity" criterion is meant that a local authority must be able to cope with fiscal losses in case a local public enterprise is running a deficit.

The third criterion, the "subsidiarity clause", is not contained in all municipal ordinances. Even where subsidiarity clauses are included, they vary in meaning. In some cases the clause may imply that local public enterprises can only become active if the »narrow subsidiarity clause« is fulfilled, i.e. the public purpose in question cannot be fulfilled more effectively by private suppliers. In others, the "simple subsidiarity clause" states that proof of performance parity between public and private companies is sufficient. The narrow subsidiarity clause can be found in federal states such as Bavaria, the Rhineland-Palatinate and Thuringia; the simple subsidiarity clause is exercised in Mecklenburg-Western Pomerania, Lower Saxony, Saarland, Saxony, SaxonyAnhalt and Schleswig-Holstein. In practice, both the narrow and the simple subsidiarity clauses leave scope for interpretation because deciding whether a private company or a public enterprise is better at fulfilling a public purpose turns out to be difficult. Finally, the »local activity« criterion is designed to exclusively restrict the decision-making competence of a local authority (and 
hence also its economic activity) to the local sphere. The snag is that the boundary of this sphere of responsibility is not always precisely defined.

In political practice, it ultimately largely boils down to whether expanding local government economic activity violates the aforementioned legal conditions regarding the fulfillment of a "public purpose« and »restriction to local activity« (Henneke, 1994, p. 38f.). From a public finance perspective, emphasizing the "public purpose" implies the economic justification of governmental activity usually discussed within the theory of public goods. Moreover, reference to »local activity « contains a link to the theory of fiscal federalism with its focus on the spatial range of the provision of public goods.

\section{Considerations from a public goods perspective}

Under a free-market system the private sector is granted priority over government (and also municipal) economic activity. The reason for this is the assumed private sector's generally higher efficiency when it comes to commercial activity compared to public sector (Hayek, 1937; Musgrave \& Musgrave 1989; Bailey, 1995). These differences in efficiency are particularly important when the expansion of municipal economic activity is assessed.

\subsection{Structurally related inefficiencies in local public economic activity}

When municipal companies compete with private firms, there is, as far as competition is concerned, initially nothing wrong with local public economic activity. What is economically decisive is the extent. When municipal companies become larger, local governments tend to reduce their being exposed to market forces. In Germany, the chances of private companies are often relatively poor in those areas where local public companies are active, the latter being systematically advantaged over their private competitors (Fuest et al., 2002; Bardt \& Fuest, 2007). This even goes so far, that private suppliers are sometimes completely barred from the market - for example in the supply of water and gas as well as in the areas of sewage disposal and rubbish collection, all of which are big earners for municipal companies. And wherever competition does exist, public suppliers are still privileged: local public companies frequently do not pay value added tax, cooperation income tax or the local business tax because they can declare their commercial activity to be a sovereign task.

Furthermore, efficient market results can only be expected if it can be ensured that the commercial risk (including bankruptcy) is completely internalized. Yet in the case of public companies there is a good chance that if it comes to the crunch, commercial risk will be "socialized " by the local public budget. With this bail-out mechanism in place, there is no pressure to calculate prices at full cost - meaning equivalent or similar products can be offered by municipal companies at much lower prices than their private competitors. Moreover, 
the prospect of public refinancing also means that municipal companies enjoy higher credit-rating with private banks, including the chance of better lending terms. Other distortions of competition are to be expected if municipal companies have unjustified advantages owing to their close links to the public sector, for instance in the award of public contracts.

\subsection{Local public economic activity as provision of public goods?}

If the efficiency enhancing effect of markets is limited for municipal companies, market allocation looses much of its effectiveness. In overall economic terms, production will take place at unnecessarily high costs and with a mismatch concerning consumer preferences. Moreover, local public economic activity may even damage the interest of a local authority. If, for example, municipal companies can drive private competitors out of the market thank to unfair competitive advantages, this will have repercussions for the local authority's tax revenue. More obvious of course are the burdens on municipal budgets whenever a municipal company's »new business idea " fails to catch on, effecting the necessary staff lay-offs will be harder for the local authority concerned than for private companies, owing to the stricter labor legislation in force for the public sector in Germany.

But apart from such budgetary considerations, convincing reasons are required to justify local public economic activity in the first place. From a public finance viewpoint, (local) government activity is only regarded as legitimate if the market fails to provide the goods and services or if the results achieved on the market have to be augmented by the government in order to satisfy public needs (Musgrave \& Musgrave 1989; Bailey, 1995). What is at stake here is the area of public good; accordingly, government units ought only to become active if the goods provided by private actors are inadequate (e.g. production costs are too high without matching costumers' preferences) and, if moreover, government provision will bring about better results. However, it is vital to note that the necessity of the municipal provision of a good or service does not automatically entail its municipal production (Rosen, 1992). Instead, production can be left to private suppliers, even in the area of public goods. This is the case if the quantity and quality of supply are regulated by government standards. This distinction between "provision « and "production« has major consequences for the assessment of an expansive business policy on the part of municipal companies.

Against this background, local public economic activity can only be regarded as expedient if it involves a necessary item of public supply, and if equivalent private production is impossible. Regarding the new fields of economic activities under discussion in Germany for municipal companies, this will only apply in extremely few cases (if any at all). For example, economically speaking there is nothing wrong with utility services such as electricity, gas and water supply, sewage disposal and rubbish collection, or telecom services being organized largely privately, as long as governmental regulations are met 
and the monitoring costs incurred are not disproportionately high. Therefore, local authorities should steer clear of expanding their own economic activity (»production« in the above sense) in these areas.

Completely unjustified in terms of public finance considerations are such new economic activities by local authorities as running hotels and restaurants, solariums and fingernail studios, travel agencies, tourism services (e.g. sunshade or bicycle hire, setting up and managing campsites) or even opening municipal food retail outlets (as it has happened in the last two decades in Germany). None of those activities have any of the characteristics of a public good, and so municipal activity in these areas has no economic legitimacy whatsoever. This is all the more the case since these activities are generally exclusively fiscally motivated. From a public finance viewpoint, the fiscal aim is merely a secondary rather than an original aim of public finance.

\section{Considerations from a fiscal federalism viewpoint}

From the angle of the theory of fiscal federalism, citing the provision of public goods as a criterion is by itself not enough to justify local public economic activities (Ter-Minassian, 1997; Oates, 1998; Wellisch, 2000). In addition, commercial activities also have to have the characteristics of local public goods (indicated by their spatial range of benefits and costs).

\subsection{Retaining the principle of fiscal equivalence}

The principle of fiscal equivalence is generally used to determine the spatial efficient character of public activity (Olson, 1969; Döring \& Voigt, 2006). This principle states that if the benefits of public services are subject of variation depending on the spatial heterogeneity of citizens' preferences, an efficient supply of public goods can only be expected if the administrative responsibility for the provision of these goods is geared to the (geographical) circle of beneficiaries who also have to finance them. The focus to the beneficiaries tailors the supply to people's preferences. Since those benefiting from public goods are the same as those bearing the production costs of them, this should ensure that the cost of the supply is minimized. In this way, the scope of public supply and the related public expenditure are subject to the decision-making powers of the citizens concerned.

Given this, cases in which municipal commercial activities extend beyond the local sphere of influence may be regarded as problematic. Particular attention is drawn to local energy utilities, which in addition to satisfying local demand also meet demand in other areas by taking over other councils' utilities. A similar situation exists in the case of local authority transport companies. From the angle of fiscal federalism, there is also the danger that during the course of such company take-overs, a spatial disparity may emerge between the beneficiaries and the cost bearers of public services. For example, if such a local concentration of supply leads to the effect that previous price 
differences, caused by the specifics of local demand, are evened out, the economically desirable allocation of costs among the public depending on those responsible for them might no longer be ensured. Moreover, the advantages of the decentralized provision local government services (i.e. taking local citizens' preferences better into account) will be abandoned without reason.

Furthermore, the theory of fiscal federalism provides an additional perspective for the assessment of the purely fiscally motivated expansion of local public economic activity. The advocates of an expansion strategy often cite the fact that ensuring local government self-administration enshrined in the German constitution also requires a minimum of public financial autonomy, and state that since this autonomy cannot be guaranteed by the existing sources of finance (taxes and transfers), local authorities must have the option of earning the missing funds by building up their economic activities (Otting, 1997b). From the viewpoint of the principle of fiscal equivalence, however, the argument veers off in the wrong direction. The financing of local government functions from revenue which is not immediately related to these functions lacks an incentive structure in the sense of fiscal equivalence: Citizens should be able to weigh the benefits of additional local public services against the resulting fiscal burdens. And if the additional expenditure of a local authority is financed by the profits earned by its companies in business transactions with citizens from other local authorities, this results in an externalization of fiscal burdens - which from the public finance perspective ought to be avoided (Feld \& Kirchgässner, 2000).

\subsection{Achieving economies of scale in production}

The principle of fiscal equivalence chiefly takes the demand-side characteristics of public goods - in this case the citizens' locally varying preferences - into consideration. However, the spatially efficient provision of public goods is also determined by supply-side characteristics (Fisher, 1996, p. 126ff). A key role in this respect is played by achieving economies of scale in production (i.e. falling unit costs owing to an increase in supply quantity). Clearly this argument bears a strong relation to especially the expansion of municipal economic activity, because it might achieve such economies of scale. Putting this argument forward, the greater usage of already existing production structures enables at the same time the deviation form a strict interpretation of the local sphere of activity of local government companies.

Instead, especially for cost-intensive aspects of providing public supply (e.g. waste disposal services), voluntary cooperation between local authorities (for instance by setting up a special purpose association) is a way of letting economies of scale work and of thus making supply less costly (Frey \& Eichenberger, 1999). Hence for reasons of cost efficiency, the catchment area supplied by a municipal company need not necessarily conform to the local authority's geographical boundary. This could even include cases 
in which products developed by a local authority that are of interest to other local authorities (e.g. the development of software services tailored to local government needs) could be marketed regionally. This would have the twin benefits of increasing the product's economic viability for the local authority developing it and of saving development costs for the other local authorities.

In this argument of the better utilization of existing production capacities which would otherwise go unused, the duration of the underutilization of the capacities should also play a role. If this situation is only temporary, expanding local government economic activity to ensure the full utilization of capacity may be justified. However, in the case of permanent underutilization the reduction of existing capacities would be the only justifiable solution. Seen from this angle, production structures not used to full capacity in the long term are nothing more than a symptom of bad public planning which needs to be corrected. An example for such bad planning at the level of local government is the waste incineration capacities built up in a whole series of German towns and cities in the last two decades, which are far too large and for this reason are the target of considerable political criticism.

\subsection{Significance for competition between local authorities}

Under the theory of fiscal federalism the question can also be raised whether the extent to which an expansion of local public economic activities can help intensify or on the other hand may even impair processes of competition between local authorities. The idea of competition between local authorities is based on the assumption that local authorities compete with each other to attract people and enterprise through their services and through the level of taxes they impose. Similar to the competition on private markets, it is assumed that in the long run those local government products will best attract among the public which are inexpensive and which match people's preferences best (Tiebout, 1956; Gerken, 1995; with focus on local government enterprises, Friedrich \& Feng, 2000). With regard to the (spatial) expansion of local public economic activity, the perspective of competition between local authorities provides justification, though within limits. This concerns above all those economic activities in which the competitors are mainly those municipal companies that belong to other town councils. For instance, the possibility of regional marketing of municipal data-processing services may result in one local authority increasing its efforts to develop a range of services better suited to its own needs. It may also result in a local authority simply using the (better) services of another in order to save the high development costs which would otherwise be picked up by its citizens.

Against this background, the possibility of one municipal company being taken over by one which belongs to a different local authority initially seems positive. In Germany, in the last two decades such take-overs especially took place in the areas of electricity and water supply as well as garbage collection. However, it is not so much the take-over as such as the option thereof which 
could generate more competition between municipal companies, resulting in the improved efficiency of the goods and services they supply. Then again, should such a hostile take-over actually take place, this will heighten the danger of supply becoming dominated by just a handful of municipal companies. The consequence would doubtlessly be a major reduction of competition between local authorities. The same situation would arise if a municipal company - say an energy utility - took the pick of the bunch by attracting large individual costumers from neighboring authorities. The utility's higher revenue would then be earned at the expense of a utility in another local authority, which would have lost large profitable customers but would still be responsible for meeting the needs of less lucrative small costumers. Rather than being advantageous for all local authorities, this form of spatial expansion of municipal economic activity would instead result in some local authorities gaining, while others significantly lose out.

\section{Some political economy considerations}

The so far overwhelmingly negative appraisal of the expansion of local public economic activity is backed up when considering the subject from the perspective of new political economy (Mueller, 1989; Johnson, 1991; Stevens 1993; regarding public enterprises, see Wiseman, 1978). From this view, municipal economic activity not only needs to be limited to the local sphere of activity, but also - and more importantly - (local) government activity needs to take second place to private-sector activities.

Justifying the expansion of local public economic activity - be it by the extensive interpretation of public aims ("securing jobs", "promoting the local economic structure», etc.) - or by reference to the »fundamental comprehensive jurisdiction of government and thus the sovereignty of the democratic legislator« (Otting, 1997b, p. 146 - own translation) - ignores from the political economy viewpoint the principal-agent problem of government activity which always exists in democratic systems based on public representation such as in Germany. Against this background, a narrow interpretation of the pursuit of public aims or even the demand that private sector activity take precedence over the public sector and would not restrict the sovereignty of (local) government but rather the discretionary room for maneuvers of bureaucrats and politicians, who do not (only) work for the general interest but also follow their own objectives (Furubotn \& Richter, 1998).

Another factor arguing against the expansion of local public economic activity is that »managers in public companies - owing to their bureaucratic organization - pay less attention to the owners' advantages than do managers working in the private sector« (Schneider, 1998, p. 12 - own translation). Furthermore, the incentive situation in public companies is comparable with that in public administrations (Niskanen, 1994). Since monetary incentives are 
largely lacking owing to rigid bureaucratic norms, public managers use their freedom of action not to boost production efficiency but rather to satisfy their own personal ambitions such as prestige or power (for example through a non-sanctioned strategy of maximizing turnover or increasing the number of employees). This theoretical view is confirmed by empirical studies revealing "significant differences in behavior between public and private managers" (Andersen, 2010, p. 131).

Ultimately, the political economy viewpoint also enables to assess the purely fiscal motive behind the expansion of local public economic activity. For this case, it also holds from this angle that a local authority's fiscal need should ideally be covered by (local) taxes, because only in this way can the government activity be tied to the public will. Although it is stipulated in the municipal ordinances in Germany that municipal tasks should primarily be financed using fees and charges before taxes, it cannot be inversely concluded that local public economic activity should be expanded simply because the goods and services offered by municipal companies are financed by fees and charges or market-like prices. The regional externalization of fiscal burdens (described above) is not the only danger; in addition, given the very low perceptibility of the existing financing system of local government in Germany (high proportion of federal transfers, low visibility of the income and turnover tax shares allocates to local government), the desirable link between the local government revenue and local public expenditure hardly exists (simply for reasons of political control). Covering the municipal fiscal need by means of commercial activity additionally confuse the already murky nature of the financing system of local councils.

\section{Conclusion}

As a result of the assessment from various theoretical angles the economic activities of local authorities appear to be admissible at best to a very limited degree. The type of business would have to be restricted to those with a strong public good content. This rules out such new economic activities by local government as running hotels, restaurants, solariums, travel agencies, catering services, flowers shops, car washes or even opening municipal food retail outlets, all of which may lead to a crowding out of private suppliers. Tapping new sources of revenue through economic activities as an end of itself is merely no original aim of local public finance. 
Thomas Döring is full Professor of Politics and Institutions, emphasizing Institutional Economics, at the Faculty of Social Sciences and Head of the Centre for Research and Development at Darmstadt University of Applied Sciences. In 1997 he obtained the title of Doctor of Economics. He is a member of the board for Institutional Economics of the German Economic Association as well as a member of the German Academy of Spatial Research and Regional Planning. His diverse research interests include Fiscal Federalism and Local Public Finance, Urban and Regional Economics as well as Environmental and Consumer Economics.

Birgit Aigner-Walder is senior scientific researcher at the Institute for Advanced Studies Carinthia. She graduated at the Faculty of Management at Carinthia University of Applied Sciences in 2005. In 2012 she obtained the title of Doctor of Economics at the University of Klagenfurt (Austria). During the years 20052011 she has been a junior scientific researcher at Carinthia University of Applied Sciences and was twice visiting research fellow at the University of Illinois at Urbana-Champaign. Her research focuses on Regional Economics and Public Finances as well as the Demographic Change and its Economic Effects (e.g. consumer behavior, labor market, services of general interest). 
Economic Activities of German Local Authorities Critical Notes from a Public Finance Perspective

\section{References}

- Andersen, J. A. (2010). Public versus Private Managers. Public Administration Review 17(1), 131-141.

- Bailey, S. J. (1995). Public Sector Economics. London.

- Bardt, H. \& Fuest, W. (2007). Die wirtschaftliche Betätigung der Kommunen. iw Trends, Nr. 3-2007. Köln.

- Baumann, B. (1993). Offene Gesellschaft, Marktprozesse und Staatsaufgaben. Baden-Baden.

- Döring, T. \& Voigt, S. (2006). Reforming Federalism German Style. Intereconomics 41(4), 201-208.

- Döring, T. (2003a). Local Governments as Entrepreneurs: Critical Notes on the Commercial Activities of German Local Authorities from a Public Finance Perspective. Philipps-Universität Marburg, Volkswirtschaftliche Beiträge, Nr. 042003. Marburg.

- Döring, T. (2003b). German Public Banks under the Pressure of the EU Subsidy Proceedings. Intereconomics 38(2), 94-101.

- European Commission (1996). Commission Communication on Services of General Interest in Europe. COM (1996) 443.

- European Commission (2000). Commission Communication on Services of General Interest in Europe. COM (2000) 580.

- Feld, L. P. \& Krichgässner, G. (2000). Income Tax Competition at the State and Local Level in Switzerland. CESifo Working Paper Series. Working Paper No. 238. München.

- Fisher, R. C. (1996). State and Local Public Finance, $2^{\text {nd }}$ ed. Chicago.

- Frey, B. S. \& Eichenberger, R. (1999). The New Democratic Federalism for Europe. Cheltenham.

- Friedrich P. \& Feng, X. (2000). The Role of Public Enterprises in Regional Competition. In Batey, P. W. J. \& Friedrich P. (Eds.). Regional Competition (186-202). Heidelberg.

- Fuest, W., Kroker, R. \& Schatz, K.-W. (2002). Die wirtschaftliche Betätigung der Kommunen und die Daseinsvorsorge. Köln.

- Furubotn, E. G. \& Richter, R. (1998). Institutions and Economic Theory, $2^{\text {nd }}$ ed. Ann Arbor.

- Gerken, L. (1995). Competition among Institutions. Basingstoke.

- Hayek, F. A. (1937). Economics and Knowledge. Economica 4(13), 33-54.

- Hrbek, R. \& Nettesheim, M. (2002). Europäische Union und mitgliedstaatliche Daseinsvorsorge. Baden-Baden.

- Johnson, D. B. (1991). Public Choice. Mountain View.

- Kuntze, Ch. (2002). Die Grenzen der erwerbswirtschaftlichen Betätigung der Kommunen. Köln.

- Meyer, L. \& Scholl, M. (1999). Wirtschaftliche Betätigung von Kommunen. Konrad-Adenauer Stiftung - Materialien für die Arbeit vor Ort, Nr. 10. Bonn.

- Mueller, D. C. (1989). Public Choice Il. Cambridge (UK).

- Musgrave, R. A. \& Musgrave, P. B. (1989). Public Finance in Theory and Practice, $5^{\text {th }}$ ed. New York.

- Niskanen, W. A. (1994). Bureaucracy and Public Economics. Aldershot.

- Oates, W. E. (1998). The Economics of Fiscal Federalism and Local Finance. Cheltenham \& Northampton. 
- Olson, M. (1969). The Principle of "Fiscal Equivalence": The Division of Responsibilities among Different Levels of Government. American Economic Review 59(2), 479-487.

- Otting, O. (1997a). Öffentlicher Zweck, Finanzhoheit und fairer Wettbewerb. Deutsches Verwaltungsblatt 112, 1258-1264.

- Otting, O. (1997b). Neues Steuerungsmodell und rechtliche Betätigungsspielräume der Kommunen. Köln.

- Rosen, H. S. (1992). Public Finance, $3^{\text {rd }}$ ed. Boston \& Sydney.

- Scherf, W. (2010). Perspektiven kommunaler Ausgabenfinanzierung. Justus-Liebig-Universität Gießen - Finanzwissenschaftliche Arbeitspapiere. Arbeitspapier Nr. 83-2010. Gießen.

- Schneider, F. (1998). Deregulierung und Privatisierung als Allheilmittel gegen ineffiziente Produktion von öffentlichen Unternehmen? University of LinzDiscussion papers, No. 9803. Linz.

- Statistisches Bundesamt (2011). Rechnungsergebnisse der kommunalen Haushalte. Fachserie 14, Reihe 3.3. Wiesbaden.

- Stevens, J. B. (1993). The Economics of Collective Choice. Boulder.

- Ter-Minassian, T. (1997). Fiscal Federalism in Theory and Practice. Washington D.C.

- Tiebout, Ch. M. (1956). A Pure Theory of Local Public Expenditures. Journal of Political Economy 64(5), 416-424.

- Wellisch, D. (2000). Theory of Public Finance in a Federal State. Cambridge (UK).

- Wiseman, J. (1978). The Political Economy of Nationalized Industry. University of New York - Reprint Series: Economics, No. 270. New York. 


\title{
GOSPODARSKE DEJAVNOSTI NEMŠKIH LOKALNIH OBLASTI: KRITIČNE OPOMBE S STALIŠČA JAVNIH FINANC
}

\author{
Ključne besede: lokalne javne finance, gospodarska ponudba lokalne uprave, \\ podjetja v lasti lokalne uprave, fiskalni federalizem, nova politična \\ ekonomija
}

V času proračunskih primanjkljajev - kar je izkusila večina lokalnih oblasti v zadnjih dvajsetih letih - se vedno pogosteje pojavljajo nove poslovne ideje, kako bi ustvarili več prihodkov. Mestni sveti se ne ustavljajo več zgolj pri oskrbovanju z električno energijo, plinom ali pri pobiranju smeti - vse to so tradicionalne lokalne dejavnosti javne uprave. Začeli so namreč ponujati različne druge proizvode in storitve podjetij, ki so v javni lasti. Te gospodarske dejavnosti so na primer prevoz, informacijska tehnologija in telekomunikacijske storitve. Nekatere lokalne oblasti imajo v lasti gramoznice, kamnolome in vinograde. Spet druge se ukvarjajo z gostinskimi storitvami, s cvetličarnami, upravljajo restavracije in hotele, potovalne agencije, energetske svetovalnice, kozmetične salone in celo avtopralnice. Drugi mestni sveti pa vozijo svoja zasebna vozila v popravilo k svojim lokalnim centrom za prevozne storitve.

Omenjeni primeri zmanjševanja proračunskega primanjkljaja z uvedbo novih gospodarskih dejavnosti nemških lokalnih oblasti nikakor niso redki; pravzaprav so v zadnjih dveh desetletjih lokalne oblasti po vsej Nemčiji povečevale svoje podjetniške dejavnosti bolj kot kdajkoli prej. V letu 2010 je 5,3 \% prihodkov lokalnih skupnosti v Zahodni Nemčiji izhajalo iz lastnih poslovnih dejavnosti, kar pomeni dvig iz 4,7 \% iz leta 1992; v Vzhodni Nemčiji se je v istem obdobju delež povečal s 4,3 \% na 5,1 \%. Tukaj so upoštevani prodaja električne energije, plina, vode ter kmetijskih in gozdarskih proizvodov, najem in zakup ter dobički iz gospodarskih podjetij in lastniški deleži družb, kakor tudi davki na licenčnine in koncesijske dajatve. $V$ celoti so prihodki iz gospodarskih dejavnosti v letu 2010 prispevali v lokalni državni proračun skoraj 9,3 milijarde €, kar je 55 odstotna porast v primerjavi s 6,0 milijardami € v letu 1992.

Za takšno trgovinsko širitev obstaja veliko razlogov, pri čemer je eden od njih spremenjeno gospodarsko okolje. Na primer, konkurenčna politika Evropske Unije zadnjih dveh desetletij je povzročila, da se tradicionalna (običajno monopolna) področja poslovanja javnih komunalnih podjetij v Nemčiji vedno bolj srečujejo z zasebno konkurenco. Ker prihodki na teh področjih upadajo, poskuša lokalna uprava izpad prihodka kompenzirati z uvajanjem novih področij poslovanja. Ta dodatni vir zaslužka za lokalne javne proračune naj bi posredno pomagal lokalnih svetom pri izpolnjevanju njihovih obveznosti. Naraščajoča trgovinska dejavnost naj bi tudi zaščitila delovna mesta v javni upravi, ki so ogrožena zaradi upadanja prihodkov iz prodaje obstoječih 
storitev javnih komunalnih podjetij. Kljub temu je ta strategija razširitve naletela na ostre kritike, njen gospodarski vpliv pa je postal predmet živahne razprave v Nemčiji. Gospodarske dejavnosti lokalne samouprave pa večinoma obsojajo tudi zasebna podjetja in poslovna združenja, ki kritizirajo neenake pogoje konkurence med zasebnimi in lokalnimi javnimi podjetji in ki trdijo, da bi gospodarske dejavnosti lokalnih oblasti morale biti omejene.

Tukaj bi morali upoštevati predvsem pravne omejitve lokalnih javnih gospodarskih dejavnosti v Nemčiji. Načeloma nemška ustava ne prepoveduje širitve lokalnih javnih gospodarskih dejavnosti, vendar pa regionalni zakoni (kot so jih sprejele nemške zvezne dežele) urejajo zakonitost teh dejavnosti v poglavjih, ki urejajo lokalno institucionalni okvir (tako imenovani občinski odloki). Čeprav se ti nekoliko razlikujejo med posameznimi nemškimi deželami, so $v$ večini od njih gospodarske dejavnosti lokalnih oblasti dovoljene, če: (1) je dejavnost utemeljena z javnim namenom; (2) vrsta in obseg dejavnosti ustrezata finančni sposobnosti lokalne oblasti in predvideni potrebi za javno službo; (3) zasebni sektor ne more več ali vsaj enako učinkovito izpolnjevati namena (tako imenovana subsidiarna klavzula); (4) se lahko lokalna oblast loti gospodarskih dejavnosti zgolj na lokalni ravni. V politični praksi le-ta v veliki meri na koncu na kratko povzema, ali naraščajoča lokalna vladna gospodarska dejavnost krši zgoraj omenjene zakonske pogoje v zvezi z izpolnjevanjem »javnega namena« in »omejitve na lokalno dejavnost«. Z vidika javnega financiranja poudarjanje »javnega namena« pomeni ekonomsko upravičenost vladne dejavnosti, ki je običajno predmet razprave v teoriji javnih dobrin. Poleg tega sklicevanje na »lokalno dejavnost« vsebuje povezavo na teorijo fiskalnega federalizma s poudarkom na prostorskem obsegu zagotavljanja javnih dobrin.

Z gospodarskega vidika ima prosti trg zasebnega sektorja prednost pred državno (in tudi komunalno) gospodarsko dejavnostjo. Vzrok za to je domnevna splošno večja učinkovitost zasebnega sektorja, ko gre za gospodarsko dejavnost v primerjavi z javnim sektorjem. Te razlike v učinkovitosti so še zlasti pomembne pri odločanju o širitvi občinske gospodarske dejavnosti. Lokalna dejavnost velja kot pravno upravičena, če trg ne zagotavlja blaga in storitev, ali če mora vlada, da bi zadovoljila javne potrebe, povečati ponudbo. Pri tem je odločujoče področje javnega dobra; zato bi lokalne enote morale postati aktivne zgolj, če so dobrine, ki jih zagotavljajo zasebni akterji, nezadostne (npr. proizvodni stroški so previsoki in ne ustrezajo preferencam strank) in če poleg tega lokalna oskrba omogoča doseganje boljših rezultatov. Kljub temu pa je pomembno opozoriti, da nujnost komunalnega zagotavljanja dobrin ali storitev samodejno ne sproža tudi komunalne proizvodnje. Namesto tega je proizvodnjo mogoče prepustiti zasebnim dobaviteljem tudi na področju javnih dobrin.

Na podlagi tega se lokalna javna gospodarska dejavnost lahko šteje za primerno samo, če vključuje nujno potrebni element javne ponudbe in enakovredna zasebna proizvodnja ni mogoča. Glede novih področij gospodarskih dejavnosti, 
ki so predmet razprave v Nemčiji, naj bi to za komunalna podjetja veljalo samo v izjemno redkih primerih (če sploh). Na primer, ekonomsko gledano ni nič narobe s komunalnimi storitvami, kot so na primer električna energija, plin in oskrba z vodo, odstranjevanje odplak in smeti ter telekomunikacijske storitve, ki se v veliki meri organizirajo na zasebni ravni, dokler so državni predpisi izpolnjeni in nastali nadzorni stroški niso nesorazmerno visoki. Zato se morajo lokalne oblasti izogibati širitvi svoje gospodarske dejavnosti (proizvodnja v prej omenjenem smislu) na teh področjih. Takšne nove gospodarske dejavnosti lokalnih oblasti kot je na primer vodenje hotelov in restavracij, solarijev in kozmetičnih salonov, potovalnih agencij, turističnih storitev (na primer izposoja senčnikov in koles, postavitev in upravljanje kampov) ali celo odpiranje maloprodajnih mest za prehrano (kot se je vse to zgodilo v zadnjih dveh desetletjih v Nemčiji) so popolnoma neupravičene z vidika javnih financ. Nobena od teh dejavnosti nima značilnosti javne dobrine, zato komunalna dejavnost na teh območjih nima nikakršne gospodarske upravičenosti.

Z vidika teorije fiskalnega federalizma sklicevanje na zagotavljanje javnih dobrin kot kriterija samo po sebi ni dovolj, da bi opravičilo lokalne javne gospodarske dejavnosti. Poleg tega morajo imeti komercialne dejavnosti tudi značilnosti lokalnih javnih dobrin (katere označuje njihov prostorski obseg koristi in stroškov). Načelo davčne enakovrednosti se običajno uporablja za določitev prostorsko učinkovitega značaja javne dejavnosti. To načelo določa, da če so koristi javnih storitev predmet spreminjanja v odvisnosti od prostorske heterogenosti preferenc državljanov, je učinkovito oskrbo z javnimi dobrinami mogoče pričakovati le, če je upravna odgovornost za zagotavljanje teh dobrin usmerjena h (geografskemu) krogu upravičencev, ki jih je tudi treba financirati. Glede na to so lahko primeri, v katerih se komunalne komercialne dejavnosti razširjajo zunaj lokalne sfere vpliva, problematični. Posebna pozornost je namenjena lokalnim javnim energetskim službam, ki poleg zadovoljevanja lokalnih povpraševanj prav tako izpolnjujejo povpraševanje na drugih področjih s prevzemanjem javnih energetskih služb drugih okolij. Podobna situacija obstaja glede prevoznih podjetij lokalnih oblasti. Z vidika davčnega federalizma obstaja tudi nevarnost, da se med prevzemom takšnega podjetja lahko pojavi prostorska neskladnost med upravičenci in nosilci stroškov javnih storitev. Poleg tega pa financiranju lokalnih vladnih funkcij iz prihodkov, ki niso neposredno povezana s temi funkcijami, primanjkuje spodbuda v smislu fiskalne enakovrednosti: državljani bi morali biti sposobni pretehtati prednosti dodatnih lokalnih javnih storitev v primerjavi z davki, ki iz tega izhajajo. Če se dodatni stroški lokalne oblasti financirajo iz dobičkov, ki so jih ustvarila njihova podjetja v poslovnih transakcijah z državljani iz drugih lokalnih skupnosti, je posledica tega eksternalizacija davčne obremenitve - kateri bi se z bilo vidika javnih financ treba izogniti.

Doslej pretežno negativna ocena razširitve lokalne javne gospodarske dejavnosti se lahko spremeni, če obravnavamo vprašanje z vidika nove politične ekonomije. S tega vidika komunalno gospodarsko dejavnost ni 
treba omejiti samo na lokalno področje delovanja, temveč mora tudi lokalna dejavnost zavzeti drugačno mesto glede na dejavnosti zasebnega sektorja, kar je še pomembneje. Opravičevanje širitve lokalne javne gospodarske dejavnosti - na primer z obširno razlago javnih ciljev (»zagotavljanje delovnih mest«, »spodbujanje lokalne gospodarske strukture», itd.) - s politično ekonomskega vidika ne upošteva problema spodbujanja državne dejavnosti, ki vedno obstaja v demokratičnih sistemih kot na primer v Nemčiji. Zato ozka razlaga zasledovanja javnih ciljev ali celo zahteve, da ima dejavnost zasebnega sektorja prednost pred javnim sektorjem, ne omejuje suverenosti (lokalne) oblasti, temveč omogoča diskrecijski prostor za manevre birokratov in politikov, ki ne delujejo (zgolj) zaradi splošnega interesa, temveč sledijo tudi lastnim ciljem.

Še en dejavnik nasprotuje širitvi lokalne javne gospodarske dejavnosti, namreč da menedžerji v javnih podjetjih - zaradi birokratske organiziranosti javnega sektorja - navadno posvečajo manj pozornosti koristim lastnikov kot menedžerji, ki delajo v zasebnem sektorju. Poleg tega pa se spodbude v javnih podjetjih lahko primerljajo s tistimi v javni upravi: ker togi birokratski predpisi precej omejujejo denarne spodbude, menedžerji v javni upravi ne uveljavljajo svobode delovanja zato, da bi povečali proizvodno učinkovitost, temveč zato, da bi zadovoljili svoje lastne ambicije, kot sta na primer prestiž in moč (na primer da bi z uvedbo nesankcionirane strategije čim bolj povečali prihodke od prodaje ali povečali število zaposlenih).

Po presoji z različnih zornih teoretičnih kotov se zdi, da so gospodarske dejavnosti lokalnih oblasti dopustne kvečjemu v zelo omejenem obsegu. Vrsta posla bi morala biti omejena na tiste dejavnosti, ki imajo velik delež javnega dobra. To izključuje večino novih gospodarskih dejavnosti lokalnih oblasti, ki lahko povzročajo izpodrivanje zasebnih ponudnikov. Poleg tega pa odpiranje novih virov prihodkov z uvajanjem novih gospodarskih dejavnosti nikakor ne more biti osnovni cilj lokalnih javnih financ. 